\title{
Preparing teachers for inclusive education
}

\author{
Clementina Acedo
}

Published online: 3 September 2011

(C) UNESCO IBE 2011

One of the greatest challenges for teacher education is posed by the demands of inclusive education but surprisingly little attention has been paid to this important topic. The 48th International Conference on Education, Inclusive Education: The Way of the Future (UNESCO IBE 2008), identified teacher education as a key area for future development. In calling upon the international community to adopt inclusive education as a way to achieve the goals of Education for All (EFA), it recommended six actions specific to teacher education and development:

1. Reinforce the role of teachers by working to improve their status and their working conditions, and develop mechanisms for recruiting suitable candidates, and retain qualified teachers who are sensitive to different learning requirements.

2. Train teachers by equipping them with the appropriate skills and materials to teach diverse student populations and meet the diverse learning needs of different categories of learners through methods such as professional development at the school level, preservice training about inclusion, and instruction attentive to the development and strengths of the individual learner.

3. Support the strategic role of tertiary education in the pre-service and professional training of teachers on inclusive education practices through, inter alia, the provision of adequate resources.

4. Encourage innovative research in teaching and learning processes related to inclusive education.

5. Equip school administrators with the skills to respond effectively to the diverse needs of all learners and promote inclusive education in their schools.

6. Take into consideration the protection of learners, teachers, and schools in times of conflict.

While these recommendations identify key areas for future development, they also raise important questions that must be addressed if future developments are to be meaningful and sustainable. For example, what does it mean to train teachers by equipping them with

C. Acedo $(\square)$

UNESCO IBE, P.O. BOX 199, 1211 Geneva 20, Switzerland

e-mail: c.acedo@ibe.unesco.org 
the appropriate skills to teach diverse student populations? How can the strategic role of tertiary education be supported in the pre-service and professional training of teachers? What kind of research in teaching and learning related to inclusive education is needed?

We know that global disparities in educational provision, and differences in teacher education and teacher qualifications within and between countries, exacerbate inequality in educational opportunity. But while the form and structure of teacher education may vary from one country to another, some common issues and challenges in providing a good quality basic education for everyone remain largely unaddressed. Inclusive education represents an area of teacher professional knowledge that is a legitimate area of concern for teacher education, regardless of national differences in form or structure. Under the auspices of inclusive education, the reform of teacher education can become more than a matter of type or level of qualification, because inclusive education is for and about everyone. It is therefore timely that this special issue of Prospects focuses on the concept of inclusive education in teacher education.

The articles in this issue focus on theoretical issues of curriculum, assessment, and teaching, and on issues of teacher professional learning. They explore how theoretical concepts associated with the development of inclusive practice are being addressed in different world regions. The issue will be of particular relevance to teachers, teacher educators, and policy makers around the world, as the role, value, and relevance of teacher education is being questioned, not only in terms of teachers' professional preparation, but also because of questions about educational outcomes for students and the extent to which teachers are able to meet the needs of all learners.

\section{Reference}

UNESCO IBE (2008). Conclusions and recommendations of the 48th session of the International Conference on Education (ED/BIE/CONFINTED 48/5). Geneva: UNESCO IBE. http://www.ibe.unesco. org/en/ice/48th-ice-2008/conclusions-and-recommendations.html. 